\title{
Risk assessment of eight metals and their mixtures to aquatic biota in sediments with diffusive gradients in thin films (DGT): a case study in Pearl River intertidal zone
}

Yang-Guang $\mathrm{Gu}^{1,2,3^{*}}$

\begin{abstract}
Background: The ecotoxicological risk posed by metals and their mixtures in sediments depends on their bioavailability. Many methods for evaluating the bioavailability of metals in sediments/soils are time-consuming and expensive, and frequently result in equivocal outcomes. The diffusive gradients in thin films (DGT) technique is a good measure of bioavailability for metals that can avoid the above drawbacks. Therefore, more effective approaches to this method should be developed that focus on metal bioavailability. No studies have been conducted using DGT to assess metal mixtures to aquatic biota in sediments. This study is therefore the first attempt to assess sediment toxicity of metals and their mixtures to aquatic biota based on the DGT technique. The intertidal zone of the Pearl River Estuary is selected as a case study.

Results: The bioavailable (DGT-labile) concentrations of metals range as follows ( $\mu \mathrm{g} / \mathrm{L}$ ): $\mathrm{Cd}, 0.34-3.62 ; \mathrm{Pb}, 1.35-1.92$; $\mathrm{Ni}, 0.67-92.83 ; \mathrm{Cu}, 0.74-10.30 ; \mathrm{Zn}, 28.60-296.94 ; \mathrm{Co}, 0.03-58.85 ; \mathrm{Fe}, 7.23-4539.36$; and $\mathrm{Mn}, 19.40-6626.83$. The risk quotient $(\mathrm{RQ})$, which is the ratio between the measured metal concentrations in the environment (MEC) and the predicted no-effect concentration (PNEC), is conducted to evaluate the single metal risk. The RQ based on summing up the MEC/PNEC ratios $\left(R Q_{M E C / P N E C}\right)$ and the $R Q$ based on sum of toxic units $\left(R Q_{S T U}\right)$ are used to assess risk of metal mixture. The RQ values of $\mathrm{Cd}, \mathrm{Pb}, \mathrm{Ni}, \mathrm{Cu}, \mathrm{Zn}, \mathrm{Fe}$, and $\mathrm{Mn}$ significantly exceed 1, indicating that the adverse effects of the metals are not negligible. Regarding the toxicity of metal mixtures, the values of $R Q_{M E C / P N E C}$ and $R Q_{S T U}$ are both between 62.45 and 743.48 , revealing that the possible risk has already occurred in the study area.
\end{abstract}

Conclusions: The two methods of $R Q_{M E C / P N E C}$ and $R Q_{S T U}$ based on DGT-labile metal concentrations are effective and suitable to estimate the toxicity of metal mixtures in sediments.

Keywords: Metals, Ecotoxicological risk assessment, Mixture toxicity, Bioavailability, Sediments

\section{Background}

The ecotoxicological hazard of metals depends on their bioavailability, which is impacted by environmental biogeochemical processes involving metal characteristics, sediment properties, and biological behavior and

\footnotetext{
*Correspondence: hydrobio@163.com

${ }^{1}$ South China Sea Fisheries Research Institute, Chinese Academy of Fishery Sciences, Guangzhou 510300, China

Full list of author information is available at the end of the article
}

physiology [1, 2]. Many of the methods for evaluating metal bioavailability in sediments/soils are both timeconsuming and expensive, and may repeatedly lead to uncertain outcomes such as sequential extraction, isotope dilution exchange method, and single-step chemical extractions [3-5]. These methods are impacted by physical and chemical factors $[4,5]$. Therefore, more effective approaches are needed.

\section{Springer Open}

(c) The Author(s) 2021. Open Access This article is licensed under a Creative Commons Attribution 4.0 International License, which permits use, sharing, adaptation, distribution and reproduction in any medium or format, as long as you give appropriate credit to the original author(s) and the source, provide a link to the Creative Commons licence, and indicate if changes were made. The images or other third party material in this article are included in the article's Creative Commons licence, unless indicated otherwise in a credit line to the material. If material is not included in the article's Creative Commons licence and your intended use is not permitted by statutory regulation or exceeds the permitted use, you will need to obtain permission directly from the copyright holder. To view a copy of this licence, visit http://creativecommons.org/licenses/by/4.0/. 
Most sediment quality guidelines (SQG) for metal evaluation are dependent upon empirical correlations of adverse biological effects and metal concentrations; ranking these has established the basis for empirical SQG in the initial tier of assessments [6, 7]. These SQG are set up mostly in terms of total metal concentrations. However, it is known that metal bioavailability in sediments relies heavily on the partitioning processes between the solid and liquid phases $[8,9]$.

The partitioning processes are strongly impacted by acid volatile sulfide (AVS), simultaneously extractable metals (SEM), organic carbon (OC), and the ions of iron and manganese $[2,10-12]$. Based on several of these factors, some equilibrium partitioning $(\mathrm{EqP})$ models, such as the AVS-SEM model, have been constructed to estimate metal bioavailability in sediments. These EqP models do not interpret metal exposure that may occur via ingestion of particles by deposit-feeding organisms [3].

Diffusive gradients in thin films (DGT) is a passive sampling technique that has been applied to evaluate labile metal concentrations in waters, soils, and sediments since 1994 [13-16], and has recently been used to predict the toxicity and bioavailability of metals to benthic organisms $[3,17,18]$. Yet, the DGT technique has rarely been used for environmental toxicology purposes to determinate the concentrations of an integrated pool of labile metals present in water and in weakened form in waters associated with sediments [3].

Concentration addition (CA) and independent action (IA) are the two classic models for predicting mixture toxicity based on the toxicities of individual metals and their concentrations in the mixture [19]. CA assumes that metals share the same mechanism, while IA infers that constituents of a mixture do not share a similar toxicity mechanism [20]. Several studies have found that the real mixture toxicity is less than the mixture toxicity of CA predictions, but higher than the mixture toxicity of IA predictions [21-23]. The CA method considers a worst-case scenario, and is most widely used to evaluate the toxicity of mixtures.

An intertidal zone is the coastal area between the high tide and low tide [24]. An intertidal zone in good condition provides a comfortable habitat for benthic and epibenthic organisms, as well as playing an important role in supporting human well-being and the global geochemical cycle $[25,26]$. As a buffer zone between sea and land, it has been affected by a high frequency of anthropogenic activities and is afflicted by the pressure of pollutants [27]. A massive of metals from land discharges into the coastal ecosystem and is deposited in the sediments. Until now, the information related to bioavailability and ecotoxicological risk of such metal mixtures based on DGT technique has not been available.
The Pearl River, which is the second largest river in China with respect to discharge amount, flows through $446,768 \mathrm{~km}^{2}$ of drainage area into the Pearl River Estuary (PRE) and finally reaches the South China Sea [28]. Unprecedented rates of development in the PRE region in the last few decades have led to the loss of $562 \mathrm{~km}^{2}$ of original intertidal marsh between 1978 and 2003 [29]. The intertidal zone ecosystem of PRE is now facing increasing pressures from heavy metal pollution due to the elevated metal discharges from different sources such as upstream discharges, domestic sewage, rock weathering or soil erosion on the mainland and runoff entering the waters [30,31]. Accordingly, the intertidal zone of the PRE was chosen as the case study in this research.

At present, only one paper reported availability and ecotoxicological risk of one metal copper in coastal environment [16]. Therefore, to our knowledge, the bioavailability and ecotoxicological risk of metals based on DGT technique are currently scarce. In this study, we use DGT technique combined with a tiered approach, mainly based on the CA concept, to integrate the risk of metal mixtures and thus provide a novel method of contaminant evaluation for the sediments.

\section{Materials and methods \\ Study area}

This study area is part of the Pearl River Estuary (PRE). The PRE is located in the south of the Tropic of Cancer, with a humid, hot and rainy tropical and subtropical monsoon climate. The annual mean temperature is $22.2{ }^{\circ} \mathrm{C}$ and the annual average precipitation is $1154.8-$ $2702.2 \mathrm{~mm}$ [32]. PRE is a bell-shaped semi-enclosed sea on the Guangdong coast of South China, occupying an area of about $2500 \mathrm{~km}^{2}$ [28]. The average annual inflow of the RRE into the sea is $1.124 \times 10^{11} \mathrm{~m}^{3}$ [32]. Water depths in the PRE vary from $2-5 \mathrm{~m}$ in the western region, to about $15 \mathrm{~m}$ in the eastern region [28]. The PRE is perennially affected by an irregular semidiurnal tide, with a tidal coefficient between 0.94 and 1.77 [32]. The ranges of water temperature, salinity, alkalinity and $\mathrm{pH}$ are 16.64 $30.09{ }^{\circ} \mathrm{C}, 0-35 \%, 1.80-2.40 \mathrm{meq} / \mathrm{L}$ and $6.5-8.58$, respectively [32-34].

\section{Sampling and analysis of sediment properties}

Undisturbed surface sediments of $0-3 \mathrm{~cm}$ were carefully gathered from 21 sites (Fig. 1) during summer tide in June 2018 using a triangular plastic spade. Five subsamples were obtained at each site and these were thoroughly mixed to achieve a typical sample. The samples from each site were then divided into half, with each part put separately into a clean plastic bag. One half of each sample was then freeze-dried, cleaned of visible debris such as rock and plant fragments, ground in a clean 


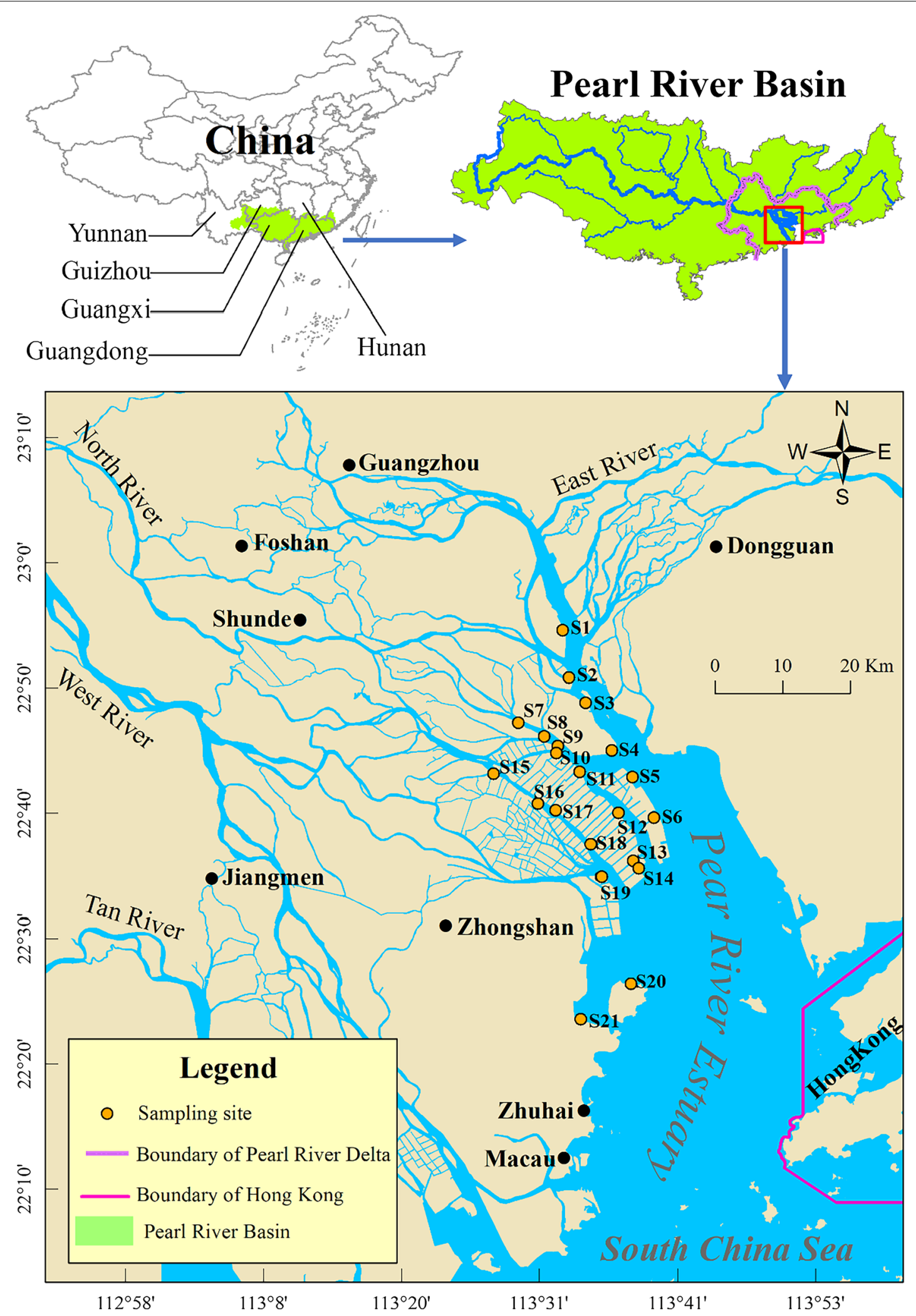

Fig. 1 Map showing the study area and sampling sites in the Pearl River Estuary intertidal zone 
mortar, passed through a $2000-\mu \mathrm{m}$ stainless-steel sieve for homogenization, and kept at $-20{ }^{\circ} \mathrm{C}$ until analysis of DGT-labile metals, organic matter (OM), and inorganic carbonate $\left(\mathrm{CaCO}_{3}\right)$. The other part of each sample was stored at $-4{ }^{\circ} \mathrm{C}$ for the determination of particle size. Details of how to determine sediment properties (OM, $\mathrm{CaCO}_{3}$, and particle size) are provided in the Additional file 1.

\section{DGT experiment}

\section{Procedure of DGT extraction}

The Chelex DGT device used in this study is composed of a binding gel $(0.40 \mathrm{~mm}$ thickness), a diffusive gel (0.90 mm thickness), and a filter membrane $(0.80 \mathrm{~mm}$ thickness) (EasySensor Ltd, www.easysensor.net). These three layers are assembled with the dual-mode holder, which consists of an "O-shape" ring, a recessed base, and a hollow base that offers structural support and accommodates the gels [35]. Target metals diffuse through the membrane filter and diffusive gel, and are accumulated on the binding gel [15]. Afterwards, the metals associated with the binding gel are extracted using acid solution for further analysis.

The DGT application procedure to measure homogenized sediments complies with the method proposed by Wang et al. [9]. Accordingly, the method involves three sequential steps: (1) pretreatment of samples; (2) DGT deployment on samples; and (3) DGT retrieval.

In initial step, sample of about $10 \mathrm{~g}$ was weighted, placed in a beaker, added deionized water to reach $70-80 \%$ water holding capacity, mixed thoroughly. The well stirred sediment was covered with plastic wrap to prevent water evaporation and incubated for $48 \mathrm{~h}$ at a constant ambient temperature.

In next step, a small amount of rehydrated sediments homogenized was added to the open cavity of the DGT device using a plastic spoon, shaken gently to ensure the sediment settles fully and was in contact with the surface of the filter membrane, with more sediment then added to completely fill the cavity. The loaded DGT device was then transferred into a plastic, semi-opened bag for incubation for $24 \mathrm{~h}$ at a constant ambient temperature, with 1-2 $\mathrm{mL}$ deionized water added to the bag to maintain moisture during deployment.

In last step, $24 \mathrm{~h}$ later, the DGT core was unscrewed and pulled out of the base using another base. The surface of the filter membrane was rinsed with deionized water and the binding gel retrieved and placed in a centrifugal tube. $1.8 \mathrm{~mL} 1 \mathrm{M} \mathrm{HNO}_{3}$ was added to the tube to immerse the gel and then the tube was closed and kept at $4{ }^{\circ} \mathrm{C}$ for $16 \mathrm{~h}$. The elution was collected for analysis of DGT-labile metals. The concentrations of $\mathrm{Cd}, \mathrm{Pb}, \mathrm{Ni}, \mathrm{Cu}, \mathrm{Zn}, \mathrm{Co}, \mathrm{Fe}$, and $\mathrm{Mn}$ were determined by inductively coupled plasma mass spectrometry (ICP$\mathrm{MS})$. Absolute difference between two independent determination results obtained under repeatability conditions not exceeded $10 \%$ of arithmetic mean value. The research work related to DGT was performed in the laboratory of EasySensor Ltd.

\section{Models for calculating DGT-labile metal concentration}

The target metal observes Fick's 1st law of diffusion in the diffusive layer. The target metal concentration from the DGT extracting solution can be transformed to a mass of metal $(M)$ through Eq. (1) as follows:

$$
M=\frac{C_{e}\left(V_{e}+V_{g}\right)}{f_{e}},
$$

where $C_{\mathrm{e}}$ is the target metal concentration in the extracting solution; $V_{\mathrm{e}}$ is the volume $(\mathrm{mL})$ of the extracting solution; $V_{\mathrm{g}}$ is the volume $(\mathrm{mL})$ of gel (in this study, $V_{\mathrm{g}}$ is $0.2 \mathrm{~mL}$ ); and $f_{\mathrm{e}}$ is extraction rate, which is 0.938 for $\mathrm{Cd}$, 0.955 for $\mathrm{Pb}, 1.05$ for $\mathrm{Ni}, 1.03$ for $\mathrm{Cu}, 0.88$ for $\mathrm{Zn}, 0.975$ for $\mathrm{Co}, 0.889$ for $\mathrm{Fe}$, and 0.967 for $\mathrm{Mn}$ [9]. The DGT-labile concentration is then calculated via Eq. (2):

$$
C_{\mathrm{DGT}}=\frac{M \triangle g}{D A t}
$$

where $\triangle g$ is the thickness of the diffusive layer and equal to $0.9 \mathrm{~mm}$ in this study; $D$ is the diffusion coefficient of the target metal, which for the studied metals relies on the EasySensor user manual (http://www.easysensor.net/ col.jsp?id=109); $A$ is the exposed surface area of the DGT device $\left(3.14 \mathrm{~cm}^{2}\right)$; and $t$ is the deployment time, which is equal to $48 \mathrm{~h}$ in this study.

\section{Toxicity data assemblage}

The acute toxic data relevant to $\mathrm{Cd}, \mathrm{Pb}, \mathrm{Ni}, \mathrm{Cu}, \mathrm{Zn}$, $\mathrm{Co}, \mathrm{Fe}$, and $\mathrm{Mn}$ were retrieved from the USEPA ECOTOX database that includes algae, crustaceans, and fish (https://cfpub.epa.gov/ecotox/). These aquatic species are from freshwater and saltwater media types.

In order to reduce errors in any species with varying acute toxicity data, and to reflect the specific metal toxicity to aquatic biota, the median values of metals in algae, crustaceans, and fish species were calculated as shown in Table 1. For fish, the EC50 values of $\mathrm{Cd}, \mathrm{Pb}$, $\mathrm{Cu}$, and $\mathrm{Zn}$ are used in this study. Due to the paucity of EC50 data for the other metals in fish species, the LC50 data of $\mathrm{Ni}, \mathrm{Co}, \mathrm{Fe}$, and $\mathrm{Mn}$ are conducted in this study. Detailed information about the values of toxicity data and aquatic species are given in the Additional file 1. 
Table 1 The acute toxicity data of the studied metals and values of predicted no-effect concentration $(P N E C)(\mu g / L)$

\begin{tabular}{|c|c|c|c|c|c|c|c|}
\hline \multirow[t]{2}{*}{ Metals } & \multicolumn{2}{|l|}{ Algae } & \multicolumn{2}{|c|}{ Crustaceans } & \multicolumn{2}{|l|}{ Fish } & \multirow[t]{2}{*}{ PNEC $^{\mathrm{b}}$} \\
\hline & EC50 & $N^{a}$ & EC50 & $N$ & EC50/LC50 & $N$ & \\
\hline $\mathrm{Cd}$ & 210.5 & 210 & 99.4 & 292 & 1490 & 35 & 0.099 \\
\hline $\mathrm{Pb}$ & 1540 & 55 & 1941.5 & 28 & 1770 & 5 & 1.540 \\
\hline $\mathrm{Ni}$ & 596 & 95 & 4389.4 & 81 & 30,000 & 132 & 0.596 \\
\hline $\mathrm{Cu}$ & 120 & 509 & 70.7 & 936 & 133.8 & 58 & 0.071 \\
\hline $\mathrm{Zn}$ & 738 & 243 & 913.5 & 286 & 1010 & 132 & 0.738 \\
\hline Co & 10,378 & 26 & 7116.5 & 14 & 96,620 & 63 & 7.117 \\
\hline $\mathrm{Fe}$ & 10,000 & 10 & $24,500.0$ & 25 & 20,000 & 176 & 10.000 \\
\hline $\mathrm{Mn}$ & 11,112 & 15 & $33,400.0$ & 22 & $130,232.5$ & 40 & 33.400 \\
\hline
\end{tabular}

${ }^{\mathrm{a}} \mathrm{N}$ is the numbers of toxicity data

${ }^{b}$ PNEC is calculated based on acute toxicity data in algae, crustaceans, and fish, with the minimum level selected and then divided by the assessment factor (=1000) $[18,38]$

\section{Ecotoxicological risk model Single metals}

The risk quotient (RQ), which is the ratio between the measured metal concentrations in the environment (MEC) and the predicted no-effect concentration (PNEC), is used to evaluate the ecotoxicological risk for each DGT-labile metal as given in Eq. (3):

$$
\mathrm{RQ}=\frac{\mathrm{MEC}}{\mathrm{PNEC}}
$$

Table 1 explains how to calculate the PNEC and gives the values obtained in this study. The RQ is considered a robust method for assessing single pollutant ecotoxicology risk and is widely used in environment studies $[19,36,37]$. An RQ value less than 1 indicates no potential ecotoxicological risk, while an RQ value higher than 1 suggests a potential ecological risk and that the environmental risk posed should not be excluded [28, 38]. A larger value indicates a greater potential risk.

\section{Mixture of metals}

The RQ for the mixture based on MEC/PNEC ratios $\left(\mathrm{RQ}_{\mathrm{MEC} / \mathrm{PNEC}}\right)$ and the RQ for the mixture based on toxic units $\left(\mathrm{RQ}_{\mathrm{STU}}\right)$ are acceptable and extensively used models $[19,38,39]$. The two models are as follows in Eqs. (4)-(5):

$$
\mathrm{RQ}_{\mathrm{MEC} / \mathrm{PNEC}}=\sum_{i=1}^{n} \mathrm{RQ}_{i}=\sum_{i=1}^{n} \frac{\mathrm{MEC}_{i}}{\mathrm{PNEC}_{i}},
$$

where AF is the assessment factor $(=1000)$ [38].

In both models, if the RQs exceeded 1, the environmental risk posed by the mixture should be considered. The risk assessment was constructed considering firstly all the metals, and later only the metals with RQ below 1 , to evaluate the potential risk of this mixture too [33].

\section{Statistical analysis}

Prior to factor analysis (FA), the normal distribution of each sediment-property variable and DGT-labile metal concentration was tested, which showed that only OM fitted normality. Therefore, the contents of $\mathrm{Cd}, \mathrm{Ni}, \mathrm{Cu}$, $\mathrm{Co}, \mathrm{Fe}$, and $\mathrm{CaCO}_{3}$ were log-transformed, and the concentrations of $\mathrm{Pb}, \mathrm{Zn}, \mathrm{Mn}$, and the median grain size were transformed with the Box-Cox method. These transformed parameters then fitted normal distributions. The transformed parameters and OM were ultimately standardized for FA. Data transformations were conducted with StatSoft STATISTICA 8.0 and FA was implemented with IBM SPSS Statistics 19.0.

\section{Results and discussion}

\section{Physicochemical properties of sediments}

$\mathrm{OM}, \mathrm{CaCO}_{3}$, and particle size composition were determined to find the general properties of sediments in this study; these are given in Additional file 1: Table S1. The OM content was between $1.44 \%$ and $14.91 \%$ with a mean of $7.42 \%$, and the $\mathrm{CaCO}_{3}$ content ranged between $0.76 \%$ and $17.26 \%$ of the dry sediment weight with a mean of

$$
\begin{aligned}
\mathrm{RQ}_{\mathrm{STU}} & =\max \left(S \mathrm{SU}_{\mathrm{algae}}, \mathrm{STU}_{\text {crustaceans }}, \mathrm{STU}_{\mathrm{fish}}\right) \times \mathrm{AF} \\
& =\max \left(\sum_{i=1}^{n} \frac{\mathrm{MEC}_{i}}{\mathrm{EC} 0_{i, \text { algae }}}, \sum_{i=1}^{n} \frac{\mathrm{MEC}_{i}}{{\mathrm{EC} 50_{i, \text { crustaceans }}}_{i}}, \sum_{i=1}^{n} \frac{\mathrm{MEC}_{i}}{\mathrm{EC} 0_{i, \text { fish }}}\right) \times \mathrm{AF},
\end{aligned}
$$


$2.68 \%$. The median grain size (MZ) varied from 2.31 to 7.06 phi $(\Phi)$ with an average of $5.24 \Phi$.

It is well established that $\mathrm{OM}$ and particle size are crucial controlling factors that alter natural metal content sediments $[40,41]$. In addition, $\mathrm{CaCO}_{3}$ plays a role in influencing natural metal distribution [42]. Sediment with a smaller grain diameter is prone to present relatively high metal contents, due in part to specific surface area. This enrichment is primarily ascribed to surface adsorption and ionic attraction [40]. Meanwhile, OM is frequently found on particles in smaller sediments, and the biofilm binds a range of trace metals [43]. The unitary linear regression relationships between $\mathrm{MZ}$ and $\mathrm{OM}$ and $\mathrm{CaCO}_{3}$ are shown in Fig. 2. Except at sites S3 and S16, OM content increases with an increase of $\Phi$ value (Fig. 2A). Sites S3 and S16 deviate from the linear trend, which could be due to localized sediment composition. For example, site S3 is located in mangrove forest, where sediment is composed mainly of sand (Fig. 2C). Mangrove forest can affect $\mathrm{OM}$ content in sediments. Site S16 is located in Spartina alterniflora wetland (Fig. 2D), where sediment has highest OM content among all the sampling sites (Fig. 2A). In the relationship between $\mathrm{CaCO}_{3}$ and $\mathrm{MZ}, \mathrm{CaCO}_{3}$ content represents an increase with the increase of $\Phi$ value, except at site S21 which falls off the trendline, possibly due to its location in an area of shellfish aggregation (Fig. 2B).

\section{DGT-labile concentration in sediments}

The spatial distributions and concentrations of the studied metals in surface sediments using DGT technique are shown in Fig. 3 and Additional file 1: Table S1. The highest values of $\mathrm{Cd}, \mathrm{Ni}, \mathrm{Zn}$, and $\mathrm{Co}$ are found at site $\mathrm{S} 2$; the highest values of $\mathrm{Pb}, \mathrm{Cu}, \mathrm{Fe}$, and $\mathrm{Mn}$ are located at site S18, site S16, site S1, and site S7, respectively. The mean DGT-labile concentrations are as follows: $\mathrm{Mn}$ $(2327.80 \mu \mathrm{g} / \mathrm{L})>\mathrm{Fe}(604.03 \mu \mathrm{g} / \mathrm{L})>\mathrm{Zn}(52.13 \mu \mathrm{g} / \mathrm{L})>\mathrm{Ni}$ $(10.18 \mu \mathrm{g} / \mathrm{L})>\mathrm{Co} \quad(8.04 \mu \mathrm{g} / \mathrm{L})>\mathrm{Cu} \quad(2.90 \mu \mathrm{g} / \mathrm{L})>\mathrm{Pb}$ $(1.46 \mu \mathrm{g} / \mathrm{L})>\mathrm{Cd}(0.79 \mu \mathrm{g} / \mathrm{L})$. DGT-labile metal concentrations $(\mu \mathrm{g} / \mathrm{L})$ in surface sediments of this study area demonstrated wide variations with $\mathrm{Cd}, 0.34-3.62 ; \mathrm{Pb}$, 1.35-1.92; Ni, 0.67-92.83; Cu, 0.74-10.30; Zn, 28.60296.94; Co, 0.03-58.85; Fe, 7.23-4539.36; and Mn, 19.406626.83. The use of plastic sieves for trace metal analysis
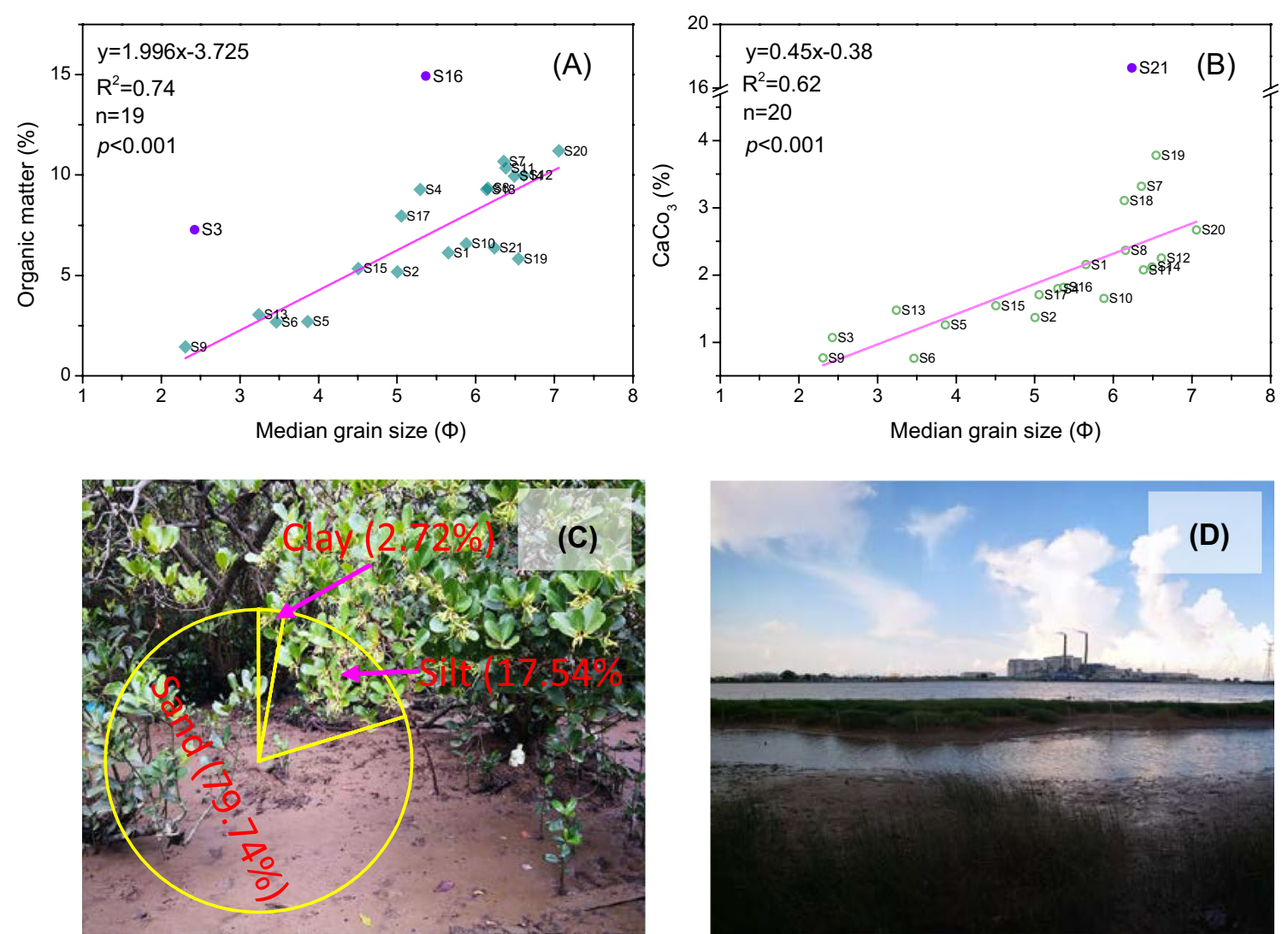

Fig. 2 Correlations between median grain size and organic matter $(\mathbf{A})$ and $\mathrm{CaCO}_{3}(\mathbf{B})$. The scenarios of sampled sites S3 (C) and S16 (D); clay $(<4 \mu \mathrm{m})$, silt $(4-63 \mu \mathrm{m})$, and sand $(63-2000 \mu \mathrm{m})$ 

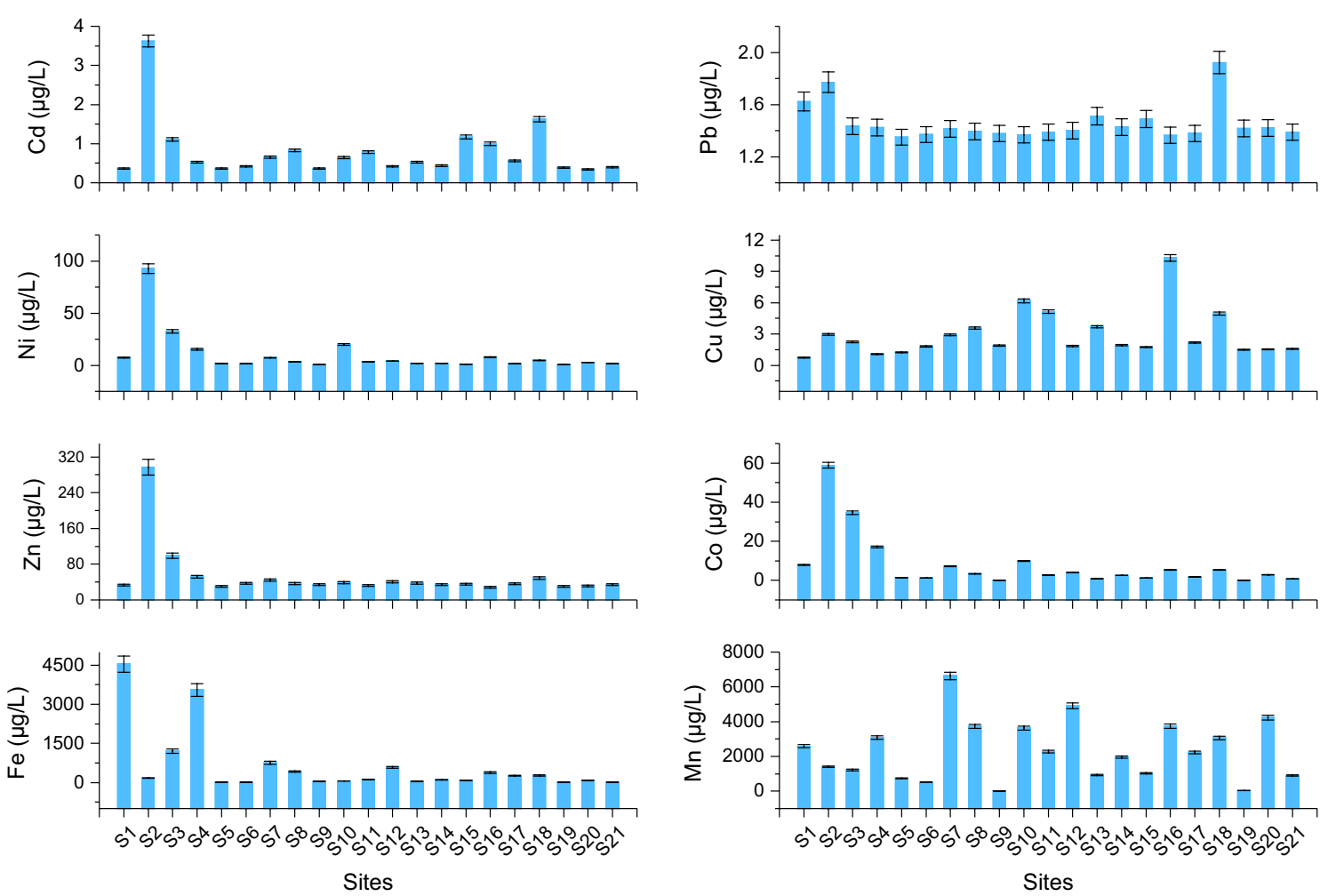

Fig. 3 The spatial distributions of DGT-labile metals in surface sediments of the Pearl River intertidal zone. Error bar is the standard deviation (SD) of replicate measurements of metals

is recommended by United Nations [44]. However, the stainless-steel sieve during the preparation of the sediment is used in this study. Generally, the stainless-steel sieve contains $\mathrm{Ni}, \mathrm{Fe}$ and Co. Consequently, the $\mathrm{Ni}, \mathrm{Fe}$ and Co data may be a little overestimate because of the contact of the sediment with the stainless-steel sieve during the preparation of the samples.

In order to identify possible relationships between sediment-property parameters and DGT-labile metals, FA with the principal component method was performed on the data. In this study, FA (VARIMAX rotation mode) was conducted to identify four factors (Fs) extracted in terms of eigenvalues $(>1)$, representing $85.88 \%$ of the data. The communalities interpreted by the variables (sediment-property parameters and DGT-labile metals), considering four Fs, vary from $77.6 \%$ for $\mathrm{Pb}$ to $95.1 \%$ for $\mathrm{Cu}$. All variables are well represented by the four Fs (F1, F2, F3, and F4), accounting for $27.07 \%, 25.45 \%, 19.44 \%$, and $13.92 \%$ of the data, respectively. The loadings of metals and the sediment-property parameters and factor scores for the investigated sites are tabulated in Table 2. $\mathrm{F} 1$ has strong positive loadings for $\mathrm{Ni}, \mathrm{Co}, \mathrm{Fe}, \mathrm{Mn}$, and $\mathrm{OM}(>0.5)$, indicating that OM mainly influences the metals of $\mathrm{Ni}, \mathrm{Co}, \mathrm{Fe}$, and $\mathrm{Mn}$ in the $\mathrm{F} 1$ sites that score $>0$;
F2 is loaded with $\mathrm{Cd}, \mathrm{Pb}, \mathrm{Ni}, \mathrm{Zn}$ and $\mathrm{Co}(>0.5)$, indicating that no sediment-property parameter influences the metals of $\mathrm{Cd}, \mathrm{Pb}, \mathrm{Ni}, \mathrm{Zn}$ and $\mathrm{Co}$ in the $\mathrm{F} 2$ sites of score $>0$; F3 represents heavy positive loading for $\mathrm{OM}, \mathrm{CaCO}_{3}$, and $\mathrm{MZ}(>0.5)$ and F4 has only heavy positive loading for $\mathrm{Cu}$ $(>0.5)$, suggesting that no sediment-property parameter influences the metals in the F3 sites (score >0) and F4 sites (score $>0)$.

\section{Ecotoxicological risk assessment Risk for individual metals}

The RQ values for each single metal in surface sediments are illustrated in Fig. 4 and Additional file 1: Table S2. The average values of RQ follow the sequence: $\mathrm{Zn}>\mathrm{Mn}>\mathrm{Fe}$ $>\mathrm{Cu}>\mathrm{Ni}>\mathrm{Cd}>\mathrm{Co}>\mathrm{Pb}$. Based on the one-sample $t$-test $(P<0.05)$, the RQ values of $\mathrm{Cd}, \mathrm{Pb}, \mathrm{Ni}, \mathrm{Cu}, \mathrm{Zn}, \mathrm{Fe}$, and $\mathrm{Mn}$ are significantly above 1 , suggesting that the adverse ecological effects of these metals are not negligible. In detail, the RQ values of $\mathrm{Cd}, \mathrm{Ni}, \mathrm{Cu}, \mathrm{Zn}, \mathrm{Fe}$, and $\mathrm{Mn}$ at all sites are higher than the threshold value of 1 ; the RQ values of $\mathrm{Pb}$ and $\mathrm{Co}$ exceed the threshold value at three sites (14.29\%) for $\mathrm{Pb}$ and six sites (28.57\%) for Co, indicating that these metals may be originated from anthropogenic input of metals. 
Table 2 Loadings of variables on VARIMAX rotated factors of the variables and factor scores for sites

\begin{tabular}{|c|c|c|c|c|c|c|c|c|c|}
\hline \multicolumn{5}{|c|}{ Loadings } & \multicolumn{5}{|c|}{ Factor scores } \\
\hline Metal & F1 & F2 & F3 & F4 & Site & F1 & F2 & F3 & F4 \\
\hline $\mathrm{Cd}$ & 0.12 & 0.77 & -0.12 & 0.54 & S1 & 0.97 & 0.43 & 0.17 & -2.33 \\
\hline $\mathrm{Pb}$ & -0.02 & 0.86 & 0.17 & -0.12 & S2 & -0.16 & 3.11 & -0.55 & 0.55 \\
\hline $\mathrm{Ni}$ & 0.63 & 0.62 & -0.17 & 0.19 & S3 & 0.92 & 1.09 & -1.56 & -0.18 \\
\hline $\mathrm{Cu}$ & 0.09 & 0.05 & 0.01 & 0.97 & S4 & 1.61 & 0.21 & -0.51 & -1.37 \\
\hline Zn & 0.27 & 0.82 & -0.27 & -0.01 & S5 & -0.70 & -0.91 & -1.10 & -0.67 \\
\hline Co & 0.75 & 0.54 & -0.08 & 0.14 & S6 & -0.92 & -0.61 & -1.48 & -0.14 \\
\hline $\mathrm{Fe}$ & 0.85 & 0.26 & -0.03 & -0.16 & S7 & 1.33 & -0.13 & 0.76 & 0.17 \\
\hline$M n$ & 0.82 & -0.07 & 0.37 & 0.22 & S8 & 0.53 & -0.31 & 0.33 & 0.63 \\
\hline OM & 0.68 & -0.13 & 0.52 & 0.39 & S9 & -1.37 & -0.93 & -1.49 & -0.45 \\
\hline $\mathrm{CaCO}_{3}$ & -0.07 & 0.04 & 0.90 & -0.07 & S10 & 0.47 & -0.31 & -0.42 & 1.30 \\
\hline \multirow[t]{11}{*}{$\mathrm{MZ}$} & 0.25 & -0.15 & 0.88 & 0.04 & S11 & 0.04 & -0.50 & 0.41 & 1.29 \\
\hline & & & & & $\mathrm{S} 12$ & 1.16 & -0.52 & 0.58 & -0.52 \\
\hline & & & & & $\mathrm{S} 13$ & -1.12 & 0.27 & -0.69 & 0.27 \\
\hline & & & & & S14 & 0.06 & -0.42 & 0.65 & -0.25 \\
\hline & & & & & S15 & -0.90 & 0.43 & -0.33 & -0.06 \\
\hline & & & & & S16 & 0.93 & -1.07 & -0.14 & 2.45 \\
\hline & & & & & S17 & 0.18 & -0.65 & -0.41 & -0.07 \\
\hline & & & & & $\mathrm{S} 18$ & -0.43 & 1.83 & 1.19 & 0.88 \\
\hline & & & & & S19 & -1.83 & -0.36 & 1.24 & -0.43 \\
\hline & & & & & S20 & 0.61 & -0.78 & 1.33 & -0.49 \\
\hline & & & & & S21 & -1.38 & 0.12 & 2.01 & -0.58 \\
\hline
\end{tabular}

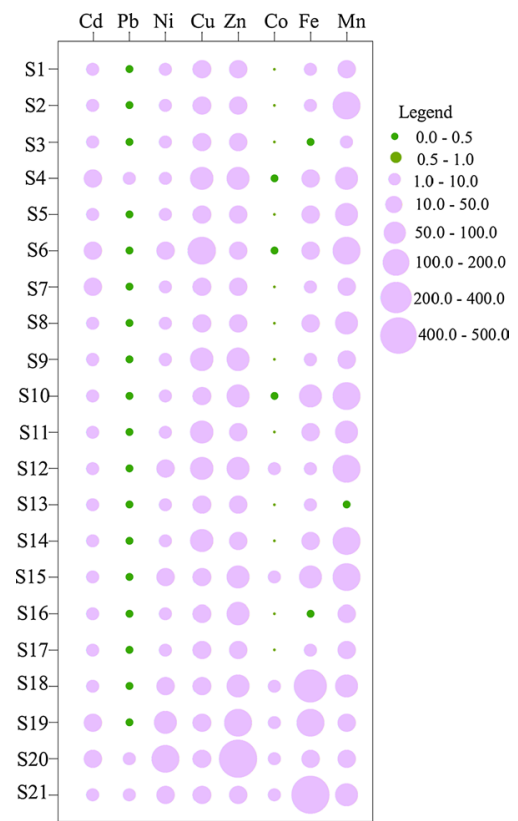

Fig. 4 Values of $R Q$ for each metal and each sampling site in surface sediments of the Pearl River intertidal zone
The overall results show that ecotoxicological risk cannot be eliminated in the study area because most metals in most sites exceed the threshold value of 1 (Fig. 3). Therefore, further detailed study should be implemented as soon as possible based on current directives.

\section{Risk for metal mixtures}

To achieve a greater predictable ecotoxicological risk assessment, we also evaluate the integrated risk of metal mixtures in surface sediments. As discussed, the RQ for the mixture based on MEC/PNEC ratios $\left(\mathrm{RQ}_{\mathrm{MEC} / \mathrm{PNEC}}\right)$ and the $R Q$ for the mixture based on toxic units $\left(R_{\mathrm{STU}}\right)$ are two methods widely used to estimate the combined toxicity of pollutant mixtures $[18,35]$.

Table 3 provides the STUs for aquatic organisms of three different trophic levels, as well as the RQs in terms of the MEC/PNEC ratios $\left(\mathrm{RQ}_{\mathrm{MEC} / \mathrm{PNEC}}\right)$ and the STUs (RQSTU). The values of $\mathrm{RQ}_{\mathrm{MEC} / \mathrm{PNEC}}$ and $\mathrm{RQ}_{\mathrm{STU}}$ are in the ranges of 70.77-704.83 and 62.45-743.48, respectively, indicating the possible risk. Generally, the RQs computed with the two methods were not different (Table 3). The risk assessment was computed firstly considering all the metals with MEC/PNEC higher than 1, and later considering only the metal with MEC/PNEC less than 1 when considered singly. In this study, the RQs were above 1 for 
Table 3 Ecotoxicological risk assessment of metal mixtures in surface sediments of the Pearl River intertidal zone

\begin{tabular}{lllllr}
\hline Site & STU & & & RQ $_{\text {STU }}$ & RQ $_{\text {MEC/PNEC }}$ \\
\cline { 2 - 4 } & Algae & Crustaceans & Fish & & \\
\hline S1 & 0.75 & 0.32 & 0.29 & 753.87 & 604.86 \\
S2 & 0.75 & 0.48 & 0.34 & 750.31 & 704.83 \\
S3 & 0.45 & 0.25 & 0.19 & 446.67 & 394.07 \\
S4 & 0.74 & 0.32 & 0.26 & 742.11 & 566.90 \\
S5 & 0.13 & 0.08 & 0.05 & 125.50 & 90.02 \\
S6 & 0.12 & 0.09 & 0.06 & 118.87 & 100.23 \\
S7 & 0.77 & 0.33 & 0.16 & 773.48 & 396.34 \\
S8 & 0.47 & 0.23 & 0.11 & 467.95 & 269.32 \\
S9 & 0.07 & 0.07 & 0.05 & 71.90 & 83.56 \\
S10 & 0.48 & 0.25 & 0.12 & 475.33 & 297.18 \\
S11 & 0.31 & 0.19 & 0.10 & 313.39 & 211.54 \\
S12 & 0.58 & 0.25 & 0.12 & 581.02 & 299.47 \\
S13 & 0.18 & 0.13 & 0.08 & 176.46 & 144.68 \\
S14 & 0.26 & 0.13 & 0.07 & 255.67 & 151.38 \\
S15 & 0.17 & 0.11 & 0.06 & 172.17 & 126.66 \\
S16 & 0.52 & 0.32 & 0.15 & 518.24 & 358.91 \\
S17 & 0.30 & 0.15 & 0.08 & 299.70 & 181.01 \\
S18 & 0.43 & 0.25 & 0.13 & 428.02 & 281.55 \\
S19 & 0.06 & 0.06 & 0.04 & 62.45 & 70.77 \\
S20 & 0.45 & 0.19 & 0.08 & 451.97 & 208.58 \\
S21 & 0.15 & 0.09 & 0.05 & 147.42 & 104.61 \\
\hline
\end{tabular}

the mixture, as expected. This highlights the importance of the risk assessment for mixtures of pollutants rather than just the single pollutants.

In addition, the unitary linear regression analysis between $R_{\mathrm{MEC} / \mathrm{PNEC}}$ and $\mathrm{RQ}_{\mathrm{STU}}$ shows that $\mathrm{RQ}_{\mathrm{MEC} / \mathrm{PNEC}}$ content increases with an increase of $\mathrm{RQ}_{\mathrm{STU}}$, indicating that the two methods are effective and reliable in assessing the toxicity of metal mixtures (Fig. 5). Accordingly, further study should be carried out in the Pearl River intertidal zone.

\section{Conclusion}

Concentrations of eight metals $(\mathrm{Cd}, \mathrm{Pb}, \mathrm{Ni}, \mathrm{Cu}, \mathrm{Zn}, \mathrm{Co}$, $\mathrm{Fe}$, and $\mathrm{Mn}$ ) from surface sediment samples from the Pearl River intertidal zone are analyzed based on DGT technique. The results show that DGT-labile concentrations demonstrate crucial spatial variation in both the single metal toxicity and integrated toxicity of metal mixtures to aquatic organisms from three trophic levels (algae, crustaceans, and fish species). The RQ for single metals indicates that $\mathrm{Cd}, \mathrm{Pb}, \mathrm{Ni}, \mathrm{Cu}, \mathrm{Zn}, \mathrm{Fe}$, and $\mathrm{Mn}$ are significantly above 1 and that their ecological adverse effects are therefore not negligible. Two different methods to estimate toxicity in metal mixtures- $\mathrm{RQ}_{\mathrm{MEC} /}$

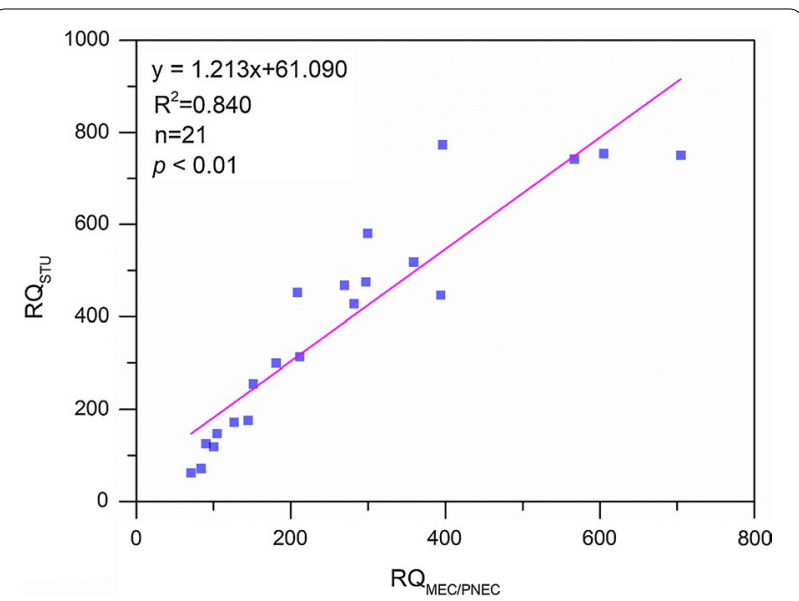

Fig. 5 The relationship between $R Q_{M E C / P N E C}$ and $R Q_{\text {STU }}$ in surface sediments of the Pearl River intertidal zone

PNEC and $\mathrm{RQ}_{\mathrm{STU}}$-demonstrate that the possible risk has already occurred in the study area. Linear-regression analysis between $\mathrm{RQ}_{\mathrm{MEC} / \mathrm{PNEC}}$ and $\mathrm{RQ}_{\mathrm{STU}}$ shows that the two methods are effective and suitable to estimate the toxicity of metal mixtures. Therefore, the ecological risk based on DGT technique should be fully taken into consideration to protect aquatic ecosystems.

\section{Abbreviations}

DGT: Diffusive gradients in thin films; RQ: Risk quotient; MEC: Measured metal concentrations in the environment; PNEC: Predicted no-effect concentration; $R Q_{M E C / P N E C}:$ The $R Q$ for the mixture based on MEC/PNEC ratios; $R Q_{\text {STU: }}: R Q$ for the mixture based on toxic units; SQG: Sediment quality guidelines; AVS: Acid volatile sulfide; SEM: Simultaneously extractable metals; OC: Organic carbon; EqP: Equilibrium partitioning; CA: Concentration addition; IA: Independent action; PRE: Pearl River Estuary; OM: Organic matter; $\mathrm{CaCO}_{3}$ : Inorganic carbonate; ICP-MS: Inductively coupled plasma mass spectrometry; PNEC: Predicted no-effect concentration; FA: Factor analysis; MZ: Median grain size.

\section{Supplementary Information}

The online version contains supplementary material available at https://doi. org/10.1186/s12302-021-00564-1.

Additional file 1. Determination of sediment properties.

\section{Acknowledgements}

Not applicable.

\section{Authors' contributions}

Y-GG did all work including study design, investigation, experiments, data curation, validation, conceptualization, manuscript writing, correction and supervision. The author read and approved the final manuscript.

\section{Funding}

This study was funded by the National Key R\&D Program of China (2019YFD0901105). 


\section{Availability of data and materials}

The datasets used and analyzed during the current study are available from the corresponding author on reasonable request

\section{Declarations}

Ethics approval and consent to participate

This article does not contain any studies with human participants or animals performed by the only author Yang-Guang Gu.

\section{Consent for publication}

The consent for publication is approved by Yang-Guang Gu.

\section{Competing interests}

Author Yang-Guang Gu declares that he has no conflict of interest.

\section{Author details}

${ }^{1}$ South China Sea Fisheries Research Institute, Chinese Academy of Fishery Sciences, Guangzhou 510300, China. ${ }^{2}$ Key Laboratory of Fishery Ecology and Environment, Guangdong Province, Guangzhou 510300, China. ${ }^{3}$ Key Laboratory of Open-Sea Fishery Development, Ministry of Agriculture and Rural Affairs, Guangzhou 510300, China.

Received: 14 June 2021 Accepted: 19 October 2021

Published online: 29 October 2021

\section{References}

1. Warren LA, Haack EA (2001) Biogeochemical controls on metal behaviour in freshwater environments. Earth Sci Rev 54:261-320

2. Jonge DM, Teuchies J, Meire P, Blust R, Bervoets $L$ (2012) The impact of increased oxygen conditions on metal-contaminated sediments part I: effects on redox status, sediment geochemistry and metal bioavailability. Water Res 46:2205-2214

3. Amato ED, Simpson SL, Jarolimek CV, Jolley DF (2014) Diffusive gradients in thin films technique provide robust prediction of metal bioavailability and toxicity in estuarine sediments. Environ Sci Technol 48:4485-4494

4. Dai YC, Nasir M, Zhang YL, Wu HM, Guo HH, Lv J (2017) Comparison of DGT with traditional methods for assessing cadmium bioavailability to Brassica chinensis in different soils. Sci Rep 7:14206

5. Kim R-Y, Yoon J-K, Kim T-S, Yang JE, Owens G, Kim K-R (2015) Bioavailability of heavy metals in soils: definitions and practical implementation-a critical review Environ Geochem Health 37:1041-1061

6. Long E, Macdonald D, Smith S, Calder F (1995) Incidence of adverse biological effects within ranges of chemical concentrations in marine and estuarine sediments. Environ Manage 19:81-97

7. Long ER, MacDonald DD (1998) Recommended uses of empirically derived, sediment quality guidelines for marine and estuarine ecosystems. Hum Ecol Risk Assess 4:1019-1039

8. Kumar M, Gogoi A, Mukherjee S (2020) Metal removal, partitioning and phase distributions in the wastewater and sludge: performance evaluation of conventional, upflow anaerobic sludge blanket and downflow hanging sponge treatment systems. J Clean Prod 249:119426

9. Wang Y, Ding SM, Gong MD, Xu SW, Xu WM, Zhang CS (2016) Diffusion characteristics of agarose hydrogel used in diffusive gradients in thin films for measurements of cations and anions. Anal Chim Acta 945:47-56

10. Teuchies J, De Jonge M, Meire P, Blust R, Bervoets L (2012) Can acid volatile sulfides (AVS) influence metal concentrations in the Macrophyte Myriophyllum aquaticum? Environ Sci Technol 46:9129-9137

11. Di Toro DM et al (2005) Predicting sediment metal toxicity using a sediment biotic ligand model: methodology and initial application. Environ Toxicol Chem 24:2410-2427

12. Nealson KH (2010) Geomicrobiology: sediment reactions defy dogma. Nature 463:1033-1034

13. Gao L, Gao B, Xu DY, Liu LH (2020) DGT: A promising technology for in-situ measurement of metal speciation in the environment. Sci Total Environ 715:136810

14. Davison W, Zhang H (1994) In situ speciation measurements of trace components in natural waters using thin-film gels. Nature 367:546-548
15. Zhang CS, Ding SM, Xu D, Tang Y, Wong MH (2014) Bioavailability assessment of phosphorus and metals in soils and sediments: a review of diffusive gradients in thin films (DGT). Environ Monit Assess 186:7367-7378

16. Umbría-Salinas K, Valero A, Martins SE, Wallner-Kersanach M (2021) Copper ecological risk assessment using DGT technique and PNEC: a case study in the Brazilian coast. J Hazard Mater 403:123918

17. Koppel DJ, King CK, Brown KE, Price GAV, Adams MS, Jolley DF (2020) Assessing the risk of metals and their mixtures in the Antarctic nearshore marine environment with diffusive gradients in thin-films. Environ Sci Technol 54:306-315

18. Amato ED, Marasinghe Wadige CPM, Taylor AM, Maher WA, Simpson SL, Jolley DF (2018) Field and laboratory evaluation of DGT for predicting metal bioaccumulation and toxicity in the freshwater bivalve Hyridella australis exposed to contaminated sediments. Environ Pollut 243:862-871

19. Riva F, Zuccato E, Davoli E, Fattore E, Castiglioni S (2019) Risk assessment of a mixture of emerging contaminants in surface water in a highly urbanized area in Italy. J Hazard Mater 361:103-110

20. Nys C, Van Regenmortel T, Janssen CR, Oorts K, Smolders E, De Schamphelaere KAC (2018) A framework for ecological risk assessment of metal mixtures in aquatic systems. Environ Toxicol Chem 37:623-642

21. Walter H, Consolaro F, Gramatica P, Scholze M, Altenburger R (2002) Mixture toxicity of priority pollutants at no observed effect concentrations (NOECs) Ecotoxicology 11:299-310

22. Junghans M, Backhaus T, Faust M, Scholze M, Grimme LH (2006) Application and validation of approaches for the predictive hazard assessment of realistic pesticide mixtures. Aquat Toxicol 76:93-110

23. Hasenbein S, Lawler SP, Geist J, Connon RE (2015) The use of growth and behavioral endpoints to assess the effects of pesticide mixtures upon aquatic organisms. Ecotoxicology 24:746-759

24. NOAA (National Oceanic and Atmospheric Administration US) (2020) What is the intertidal zone? https://oceanservice.noaa.gov/facts/inter tidal-zone.html.

25. Lv M et al (2020) A national-scale characterization of organochlorine pesticides (OCPs) in intertidal sediment of China: Occurrence, fate and influential factors. Environ Pollut 257:113634

26. Halpern BS et al (2012) An index to assess the health and benefits of the global ocean. Nature 488:615-620

27. Halpern BS et al (2008) A global map of human impact on marine ecosystems. Science 319:948-952

28. Gu YG, Gao YP, Huang HH, Wu FX (2020) First attempt to assess ecotoxicological risk of fifteen rare earth elements and their mixtures in sediments with diffusive gradients in thin films. Water Res 185:116254

29. Bai JH et al (2011) Assessment of heavy metal pollution in wetland soils from the young and old reclaimed regions in the Pearl River Estuary. South China Environ Pollut 159:817-824

30. Zhang GL, Bai JH, Xiao R, Zhao QQ, Jia J, Cui BS, Liu XH (2017) Heavy metal fractions and ecological risk assessment in sediments from urban, rural and reclamation-affected rivers of the Pearl River Estuary, China. Chemosphere 184:278-288

31. Cheung KC, Poon BHT, Lan CY, Wong MH (2003) Assessment of metal and nutrient concentrations in river water and sediment collected from the cities in the Pearl River Delta. South China Chemosphere 52:1431-1440

32. China Bay Chronicles Compilation Committee (1998) Survey of China Bays: Key Estuaries, vol 14. China Ocean Press, Beijing, pp 239-298

33. Peng YH, Chen HR, Li SF (1991) pH and Alkalinity in the water body of Pearl River Mouth. Trop Oceanol 10:49-55

34. Chen MR, Si YY, Han LY, Liu X, Huang BQ, Kang CK (2021) Effect of prey selectivity and trophic cascades induced by mesozooplankton on the dynamics of phytoplankton. Mar Ecol Prog Ser 662:35-51

35. Ding SM, Wang Y, Zhang LP, Xu L, Gong MD, Zhang CS (2016) New holder configurations for use in the diffusive gradients in thin films (DGT) technique. RSC Adv 6:88143-88156

36. Ccanccapa A, Masiá A, Navarro-Ortega A, Picó Y, Barceló D (2016) Pesticides in the Ebro River basin: occurrence and risk assessment. Environ Pollut 211:414-424

37. Meng Y et al (2019) A review on occurrence and risk of polycyclic aromatic hydrocarbons (PAHs) in lakes of China. Sci Total Environ 651:2497-2506

38. Backhaus T, Faust M (2012) Predictive environmental risk assessment of chemical mixtures: a conceptual framework. Environ Sci Technol 46:2564-2573 
39. Nika MC et al (2020) Wide-scope target analysis of emerging contaminants in landfill leachates and risk assessment using Risk Quotient methodology. J Hazard Mater 394:122493

40. Zhang LP et al (2007) Heavy metal contamination in western Xiamen Bay sediments and its vicinity, China. Mar Pollut Bull 54:974-982

41. Zhang WG, Feng H, Chang JN, Qu JG, Xie HX, Yu LZ (2009) Heavy metal contamination in surface sediments of Yangtze River intertidal zone: an assessment from different indexes. Environ Pollut 157:1533-1543

42. Gu YG (2018) Heavy metal fractionation and ecological risk implications in the intertidal surface sediments of Zhelin Bay, South China. Mar Pollut Bull 129:905-912
43. Wangersky PJ (1986) Biological control of trace metal residence time and speciation: a review and synthesis. Mar Chem 18:269-297

44. United Nations (2020) Agenda item 5: Parallel CORMON Sessions for Pollution, including Marine Litter and Biodiversity-Monitoring Guidelines/ Protocols for Sampling and Sample Preservation of Sediment for IMAP Common Indicator 17: Heavy and Trace Elements and Organic Contaminant, UNEP/MED WG.482/11

\section{Publisher's Note}

Springer Nature remains neutral with regard to jurisdictional claims in published maps and institutional affiliations.

\section{Submit your manuscript to a SpringerOpen ${ }^{\odot}$ journal and benefit from:}

- Convenient online submission

- Rigorous peer review

- Open access: articles freely available online

- High visibility within the field

- Retaining the copyright to your article

Submit your next manuscript at $\boldsymbol{\nabla}$ springeropen.com 